\title{
Release of Five Sweetpotato Cultivars in Uganda
}

\author{
R.O.M. Mwanga, B. Odongo, and C. Ocitti p'Obwoya ${ }^{1}$ \\ National Agricultural Research Organization, Namulonge Agricultural and \\ Animal Production Research Institute, P.O. Box 7083, Kampala, Uganda
}

\author{
R.W. Gibson \\ Natural Resources Institute, University of Greenwich, CentralAvenue, Chatham \\ Maritime, Kent ME4 4TB, United Kingdom
}

N.E.J.M. Smit ${ }^{2}$ and E.E. Carey ${ }^{3}$

International Potato Center, Regional Office for Sub-Saharan Africa, P.O. Box 25171, Nairobi, Kenya

Additional index words. Ipomoea batatas, sweetpotato virus disease, SPVD, Alternaria stem blight, dry matter content, Cylas puncticollis, Cylas brunneus, sweetpotato weevil

Sweetpotato [Ipomoea batatas (L.) Poir.] cultivars, Bwanjule, New Kawogo, Tanzania, Wagabolige, and Sowola were approved for release by the Ugandan Plant Variety Release Committee (Mwanga et al., 1995). These were the first sweetpotato cultivars to be officially released in Uganda, where sweetpotato is an important food crop with estimated annual production in 1998 of 2.52 million $t$ on 560,000 ha [Food and Agriculture Organization (FAO), 2000]. Per capita sweetpotato production in Uganda is estimated at $119 \mathrm{~kg}$ annually. Ugandan sweetpotato farmers grow a large number of sweetpotato landraces, many of them relatively low yielding, narrowly adapted, and susceptible to diseases and pests (Bashaasha et al., 1995).

Four of the newly released cultivars were selections from Ugandan landrace germplasm, and one (Sowola) was newly bred. All were selected on the basis of consistently superior yield performance and disease resistance in multi-locational yield trials in Uganda, and their excellent consumer acceptance in taste tests. They present Ugandan farmers with a choice of superior cultivars for improving sweetpotato production, and sweetpotato cultivar development programs outside of Uganda with a new source of germplasm with potential for use either as cultivars or progenitors.

Received for publication 8 Feb. 2000. Accepted for publication 23 Aug. 2000. The cost of publishing this paper was defrayed in part by the payment of page charges. Under postal regulations, this paper therefore must be hereby marked advertisement solely to indicate this fact.

${ }^{1}$ Deceased agronomist. This paper is dedicated to his memory.

${ }^{2}$ Former International Potato Center (CIP) entomologist. Current address: Frans Netscherlaan 27, 2071 AZ Santpoort-Noord, The Netherlands.

${ }^{3}$ To whom requests for reprints should be addressed. E-mail address: tcarey@ oznet.ksu.edu.Former CIP sweetpotato breeder, currently Associate Professor at the Kansas State Univ. Research and Extension Center at Olathe, 35125 W. $135^{\text {th }}$ St., Olathe, Kans. 66061.

\section{Origin}

'Bwanjule', 'New Kawogo', 'Tanzania', and 'Wagabolige' are superior Ugandan farmers' cultivars selected from a collection of 380 landrace accessions assembled at Namulonge Agricultural and Animal Production Research Institute (NAARI) in 1987 and subsequently evaluated in trials at NAARI and elsewhere in Uganda. Pedigrees of these landrace cultivars are not known, but they are assumed to be chance seedlings selected by farmers. On the basis of numbers of landrace cultivars, and the adaptation of these cultivars to local conditions, including diseases and pests, eastern Africa is considered to be a secondary center of sweetpotato genetic diversity.

'Sowola', designated NIS/90/389a during testing, is a seedling selection from the sweetpotato breeding program at NAARI, and was selected from bulked seed from a polycross of 18 parents made from 1989 to 1990 . The progenitors in this polycross block were popular farmers' cultivars from various parts of Uganda as follows: 'Odeyo cani', 'Bwom dege', and 'Cwara opoko', from Gulu District; 'Tanzania', from Soroti District; 'Siliki', 'Mpaeifumbiro', and 'Wagabolige', from Jinja District; 'Katalaako', from Iganga District; 'Tororo 1', 'Tororo 2', and 'Tororo 3', from Tororo District; 'Nylon', 'Bugerere', 'Sukali', and 'Mwezigumu' from Nakasongola District; and 'Nantongo', 'Kawogo', and 'Mwezigumu' from Mpigi District. Because of the open-pollinated and bulk nature of the seed population, the pedigree of 'Sowola' is not known.

At the time of official release, 'Bwanjule' and 'Wagabolige' were of localized importance in their areas of original collection in Uganda, and 'New Kawogo' and 'Tanzania' were already widely grown by Ugandan farmers. 'New Kawogo' is the predominant cultivar grown in the tall grassland agroecological zone near Kampala. 'Tanzania' is a commercially important cultivar widely grown in the drier northeastern districts of Kumi and Soroti. On the basis of morphological characteristics, performance and quality characteristics, 'Tanzania' also appears to be widely grown in Tanzania (where it is known as 'SPN/O'), Malawi (where it is known as 'Kenya'), Kenya (where it is known as 'Enaironi'), and Zambia (where it is know as 'Chingovwa'). 'Tanzania' is probably the most widely grown sweetpotato cultivar in Sub-Saharan Africa.

\section{Description and Performance}

Selected standard morphological descriptors of the five cultivars [International Potato Center (CIP), Asian Vegetable Research and Development Center (AVRDC), and International Board for Plant Genetic Resources (IBGR), 1991] are presented in Table 1 and selected quality attributes, disease and pest reactions, and agronomic characteristics in Table 2. 'Sowola' has semi-erect vines and a relatively nonvigorous canopy that does not suppress aggressive weeds as effectively as do those of the other cultivars. All five cultivars readily flower and set seed without special treatment under NAARI conditions.

All have relatively high root dry matter content and a somewhat dry texture and slightly sweet taste upon cooking. Flesh color (Table 1) is white to cream. These quality attributes are preferred by Ugandan consumers and differ markedly from the standard moist-textured, orange-fleshed 'Porto Rico'type sweetpotato predominant in the United States.

During their evaluation and selection, the released cultivars were routinely assessed for reaction to commonly occurring Ugandan diseases and pests. 'Sowola' and 'Tanzania' are shallow rooting, and in most cases their storage roots are exposed at the soil surface, making them highly susceptible to attack by sweetpotato weevils, Cylas puncticollis Bohe. and $C$. brunneus $\mathrm{F}$. The remaining cultivars are somewhat deeper rooting, leading to consistently lower weevil damage in the field. All six cultivars have moderate to high resistance to sweetpotato virus disease (SPVD), a serious disease in some environments in Uganda, and particularly severe at NAARI, where the Ugandan sweetpotato breeding program is based (Gibson et al., 1998). 'Sowola', 'Tanzania', and 'Bwanjule' are resistant to Alternaria stem blight, a severe disease on susceptible genotypes in the southwestern highlands of Uganda, and extending to production areas in Rwanda and Burundi.

\section{Availability}

The cultivars are available upon request from the CIP or from NAARI. Cultivars are maintained as pathogen-tested, in vitro plantlets at CIP, Lima, Peru. They are also maintained by CIP as pathogen-tested plants in the screenhouse at Kenya Plant Quarantine Station, Muguga, Kenya, and are maintained by NAARI in Uganda in nonpathogen-tested form. 'Bwanjule' (CIP 440168), 'New Kawogo' (CIP 441743), 'Tanzania,' (CIP 440166), and 'Wagabolige' (CIP 440167) are maintained by CIP in trust for humanity as part 
Table 1. Morphological descriptors of five sweetpotato cultivars released in Uganda. ${ }^{\mathrm{z}}$

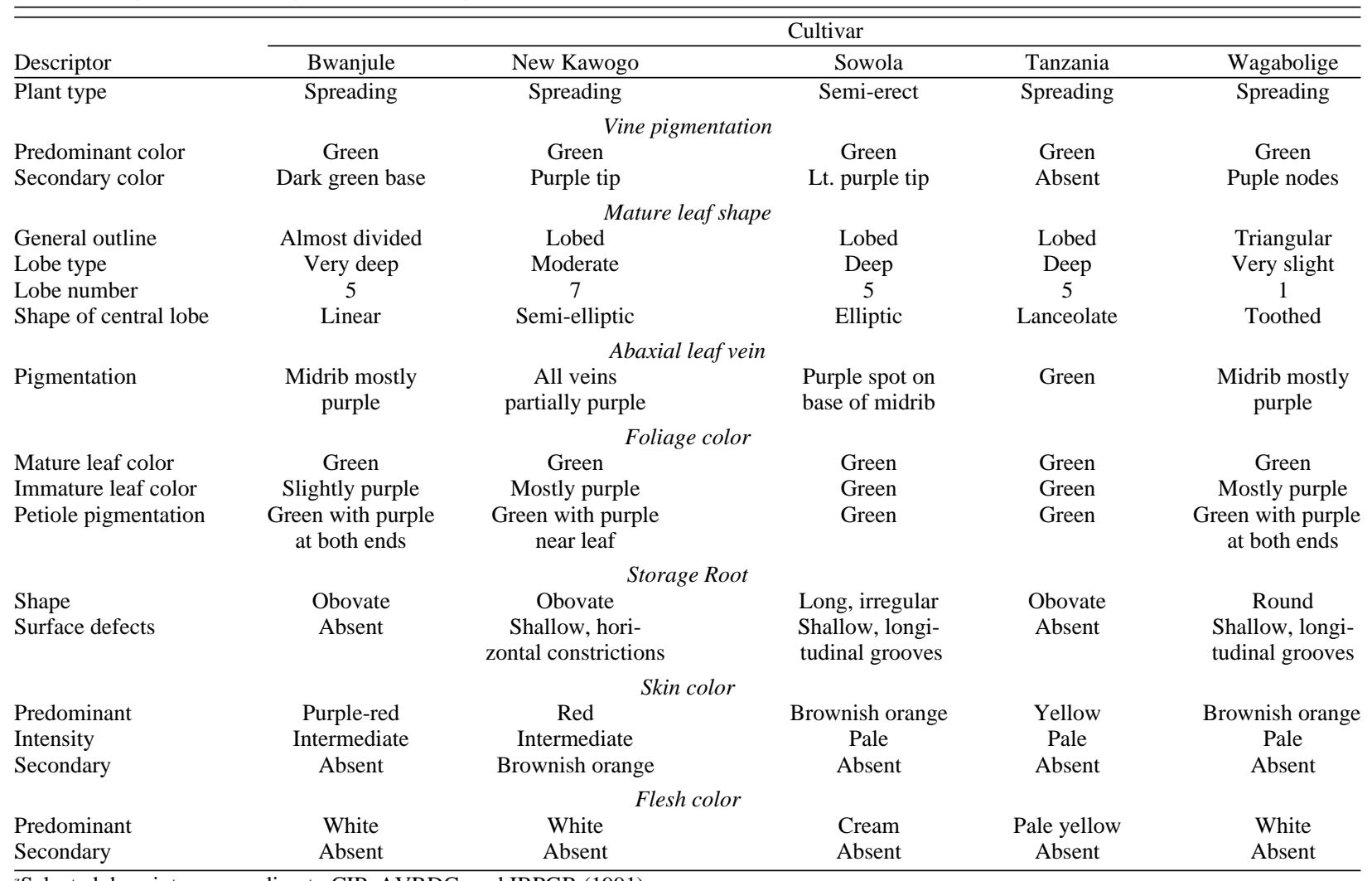

${ }^{\mathrm{z}}$ Selected descriptors according to CIP, AVRDC, and IBPGR (1991).

Table 2. Selected agronomic, disease, and pest reaction and quality attributes of six sweetpotato cultivars released in Uganda.

\begin{tabular}{|c|c|c|c|c|c|}
\hline \multirow[b]{2}{*}{ Attribute } & \multicolumn{5}{|c|}{ Cultivar } \\
\hline & Bwanjule & New Kawogo & Sowola & Tanzania & Wagabolige \\
\hline$\overline{\text { Dry matter }(\%)}$ & 30 & 32 & 34 & 32 & 33 \\
\hline Cooked texture & Somewhat dry & Somewhat dry & Somewhat dry & Somewhat dry & Somewhat dry \\
\hline Sweetness & Moderate & Moderate & Moderate & Sweet & Moderate \\
\hline Field reaction to weevils ${ }^{\mathrm{z}}$ & MR & MR & HS & $\mathrm{S}$ & MR \\
\hline Field reaction to $\mathrm{SPVD}^{\mathrm{z}, \mathrm{y}}$ & $\mathrm{R}$ & HR & MR & $\mathrm{R}$ & $\mathrm{R}$ \\
\hline Field reaction to Alternaria stem blight ${ }^{2}$ & $\mathrm{R}$ & HS & $\mathrm{R}$ & MR & HS \\
\hline $\begin{array}{l}\text { Mean and (range) of storage root yields } \\
\text { in various breeding trials ( } t / h a)\end{array}$ & $\begin{array}{c}21.4 \\
(7 \text { to } 49)\end{array}$ & $\begin{array}{c}23.3 \\
(6 \text { to } 45)\end{array}$ & $\begin{array}{c}25.6 \\
(9 \text { to } 41)\end{array}$ & $\begin{array}{c}22.9 \\
(5 \text { to } 58)\end{array}$ & $\begin{array}{c}24.1 \\
(6 \text { to } 79)\end{array}$ \\
\hline Other traits & Vigorous foliage & Vigorous foliage & $\begin{array}{l}\text { Storage roots sprout } \\
\text { easily when injured }\end{array}$ & & Vigorous foliage \\
\hline
\end{tabular}

${ }^{\mathrm{z}} \mathrm{HS}=$ highly susceptible, $\mathrm{S}=$ susceptible, $\mathrm{MR}=$ moderately resistant, $\mathrm{R}=$ resistant, and $\mathrm{HR}=$ highly resistant.

${ }^{y}$ SPVD = sweetpotato virus disease.

of the FAO's designated global sweetpotato germplasm collection, whereas 'Sowola' (CIP 441744), as the product of a joint breeding effort between CIP and NAARI, is not part of this collection. Requests for these cultivars from outside of Africa should be addressed to the Seed Unit, CIP, AA 1558, Lima, Peru. Requests within Africa should be addressed to the Seed Unit, CIP, P.O. Box 25171, Nairobi. Within Uganda, requests for planting materials should be addressed to the Sweetpotato Program, NAARI, P.O. Box 7083, Kampala.

\section{Literature Cited}

Bashaasha, B., R.O.M. Mwanga, C.O. p'Obwoya, and P.T. Ewell. 1995. Sweetpotato in the farming and food systems of Uganda: A farm survey report. International Potato Center Sub-Saharan Africa Region, Nairobi, Kenya.

International Potato Center, Asian Vegetable Research and Development Center, and International Board for Plant Genetic Resources. 1991. Descriptors for sweet potato. Z. Huaman (ed.). Intl. Bd. Plant Genetic Resources, Rome.

Food and Agriculture Organization. 2000. FAO on- line database. http://apps.fao.org.

Gibson R.W., I. Mpembe, T. Alicai, E.E. Carey, R.O.M. Mwanga, S.E. Seal, and H.F. Vetten. 1998. Symptoms, aetiology and serological analysis of sweet potato virus disease in Uganda. Plant Pathol. 47:95-102.

Mwanga, R.O.M., B. Odongo, N. Smit, C.O. p'Obwoya, and R.W. Gibson. 1995. Submission to the Variety Release Committee for release of sweetpotato varieties. The Ugandan Min. of Agr., Animal Ind. and Fisheries, Application for inclusion of a crop/variety in the National Cultivar List No. F00009. 